\title{
AKADEMIK MIROSLAV ŠICEL - VODITELJ ZAVODA ZA ZNANSTVENI RAD HRVATSKE AKADEMIJE ZNANOSTI I UMJETNOSTI U VARAŽDINU 2003. - $2011 .{ }^{1}$
}

\begin{abstract}
Tekst na pregledan $i$ dokumentiran način prikazuje aktivnosti Zavoda za znanstveni rad Hrvatske akademije u Varaždinu $u$ vrijeme kada je na njegovom čelu bio akad. Miroslav Šicel (2003. -2011.). Riječ je o svojevrsnom hommagu uglednom Varaždincu u povodu petogodišnjice njegove smrti (2011.-2016.).
\end{abstract}

\section{UVOD}

Akademik Miroslav Šicel ${ }^{2}$ izabran je za voditelja Zavoda za znanstveni rad Hrvatske akademije znanosti i umjetnosti u Varaždinu ${ }^{3}$ odlukom Predsjedništva Hrvatske akademije u ožujku 2003. godine. ${ }^{4}$

Akademik M. Šicel naslijedio na mjestu voditelja Zavoda prvog voditelja i utemeljitelja Zavoda akad. Andre Mohorovičića, ${ }^{5}$ koji je svoju dužnost obavljao do svoje smrti 2002. Do izbora novog voditelja Zavod je vodio njegov zamjenik tajnik

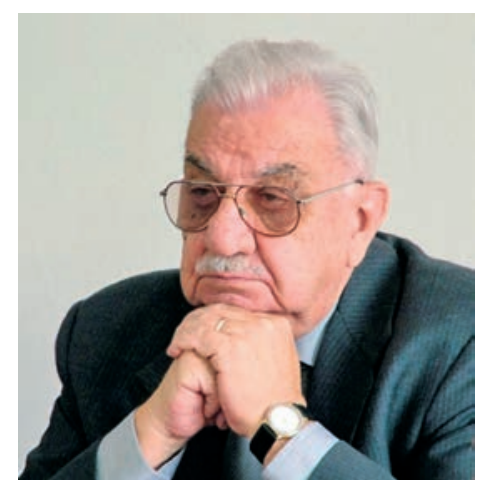

Miroslav Šicel 1926. - 2011. (Autor fotografije Dobriša Skok.)

\footnotetext{
Riječ izgovorena na Hommagu akademiku Miroslavu Šicelu u povodu 90. obljetnice rođenja. Bilo je to 4. 11. 2016. u multimedijskoj dvorani Entomološkog odjela Gradskog muzeja Varaždin. O akad. Šicelu govorili su: akademik Krešimir Nemec, Joža Skok, Ernest Fišer i autor ovog priloga. Uvodna riječ akad. Stjepan Damjanović, voditelj Zavoda u Varaždinu. Moderator je bio Vladimir Huzjan, upravitelj Zavoda.

2 Miroslav Šicel rođen je 16. kolovoza u Varaždinu, a umro 25. studenoga 2011. u Zagrebu.

3 Datum formiranja Zavoda: 24. lipnja 1983. godine.

4 Datum odluke Predsjedništva Hrvatske akademije je: 20. ožujka 2003. godine.

5 Andre Mohorovičić rođen je 12. srpnja 1913. u Križevcima, a umro 17. prosinca 2002. u Zagrebu.
} 
Akademije prof. dr. sc. Slobodan Kaštela, koji je tu funkciju obavljao i nakon izbora M. Šicela za voditelja varaždinskog Zavoda.

Godina u kojoj je akademik Šicel izabran za voditelja Zavoda bogata je događanjima koja su, uobičajeno, višegodišnja kad je riječ u projektima znanstvenih ustanova. Te 2003. godine Zavod je obilježavao 20. godina uspješnog djelovanja. Obljetnica koju smo mi u Zavodu, potpomognuti Hrvatskom akademijom, Gradom Varaždinom i Varaždinskom županijom obilježili radno, ali i prigodno. Voditelj je, može se reći, jednostavno „uletio“ u programe koji su bili u visokom stupnju realizacije.

Riječ je o slijedećim programima:

- Organizacija međunarodnog znanstvenog skupa: „Tristo godina dolaska uršulinki u Varaždin 1703. - 2003." (listopad)

- Tiskanje Zbornika radova: „Tristo godina dolaska uršulinki u Varaždin 1703. - 2003."

- Tiskanje knjige Ivana Grabara: „Dvadeset godina Zavoda za znanstveni rad Hrvatske akademije znanosti i umjetnosti u Varaždinu, 1983. - 2003.“

- U proljeće 2003. inicijativom i podrškom pročelnika Grada Varaždina dr. sc. Janka Pavetića ${ }^{6}$, te u dogovoru s Hrvatsko akademijom prišlo se obnovi prostorija Zavoda u palači Keglević u kojoj djeluje od 1990.

Prvi javni nastup novog voditelja bio je susret kod gradonačelnika Grada Varaždina dr. sc. Ivana Čehoka. ${ }^{7}$ Prisutni su bili župan Varaždinske županije dr. sc. Zvonimir Sabati, zamjenik gradonačelnika Tomislav Bogović i pročelnik Grada dr. sc. Janko Pavetić. Prijemu su, uz voditelja, prisustvovali njegov zamjenik Slobodan Kaštela, prvi i drugi upravitelji Zavoda Franjo Ruža i Ivan Grabar i aktualni upravitelj Eduard Vargović. U srdačnoj i prijateljskoj atmosferi izraženo je zadovoljstvo izborom Varaždinca akademika Miroslava Šicela za voditelja Zavoda, ali i ukupnim djelovanje Akademijinog Zavoda ne samo u Varaždinu nego i na cijelom prostoru sjeverozapadne Hrvatske. Voditelj je bio jako zadovoljan susretom i razgovorima, naglasivši pritom da će se svi programi za 2003. godinu uspješno realizirati.

\footnotetext{
Dr. sc. Janko Pavetić, pročelnik Odjela za kulturu i sport Grada Varaždina bio je i član Znanstvenog vijeća Zavoda. Kao dugogodišnji iskusan društveni djelatnik i pročelnik u Gradu, Pavetić je mnogo pomogao u aktivnostima Akademijinog Zavoda u Varaždinu, poznavajući odlično ne samo život Varaždina, već i prirodu znanstvenog djelovanja Hrvatske akademije znanosti i umjetnosti.

7 Prijam je upriličen 22. travnja 2003. godine.
} 


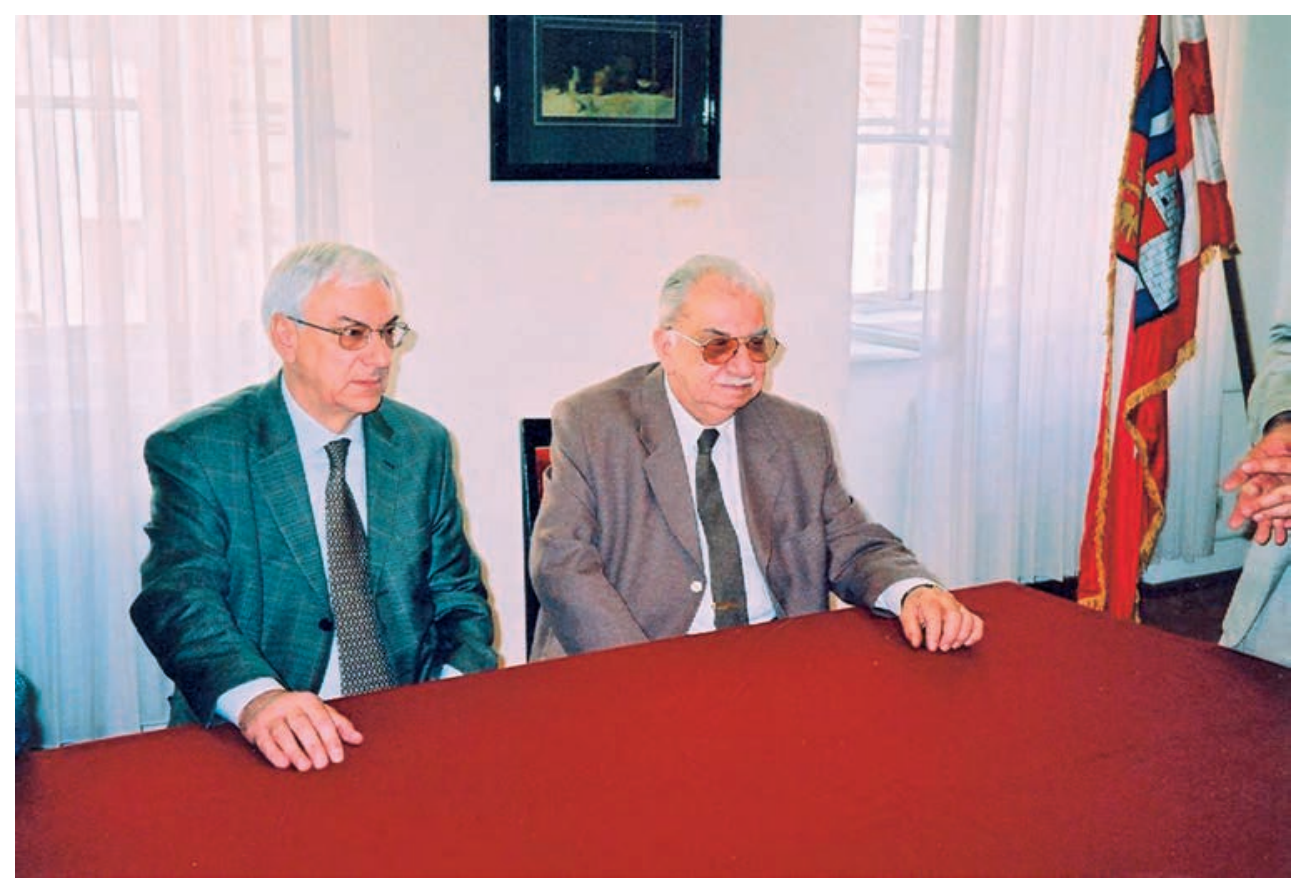

Slika 1. Akad. M. Šicel i prof. dr. sc. Slobodan Kaštela u Gradskoj vijećnici Varaždin (22. IV. 2003.)

Akademik M. Šicel brzo i odlično se snašao u novoj ulozi, iako mu je bilo jasno da je riječ o „zahuktalim“ aktivnostima koje su ga dočekale. To se pokazalo već na prvoj redovnoj sjednici Znanstvenog vijeća, koja je susretljivošću Grada Varaždina održana u njegovim prostorima. Naime, $u$ toku je bila obnova prostora u palači Keglević gdje je Zavod smješten. ${ }^{8}$ Dva su razloga, po našem mišljenju, bila ključna u njegovom brzom snalaženju. Prvi je razlog taj da je akad. Šicel Varaždinec i da dobro poznaje ljude i događanja u gradu, kao i činjenica da je surađivao s varaždinskim Zavodom, i drugi, također važan, je dobra organizacija djelovanja Zavoda koja je naslijeđena od prijašnjeg voditelja akad. Andre Mohorovičića i njegovog zamjenika tajnika HAZU prof. dr. sc. Slobodana Kaštele. Sve to je nama u Zavodu pomoglo u neposrednoj operacionalizaciji zadataka i programa, jer se s voditeljem nismo posebno trebali upoznavati, a i on je sve nas u Zavodu (dobro) poznavao. Također je bio zadovoljan s kontinuitetom rada Zavoda kao i činjenicom da svi zajedno djelujemo pridonoseći uspješnosti znanstvenoistraživačkih i nakladničkih projekata.

s Sjednica je održana 30. V. 2003. (petak) u 11 sati u Gradskoj vijećnici, Trg kralja Tomislava 1. 


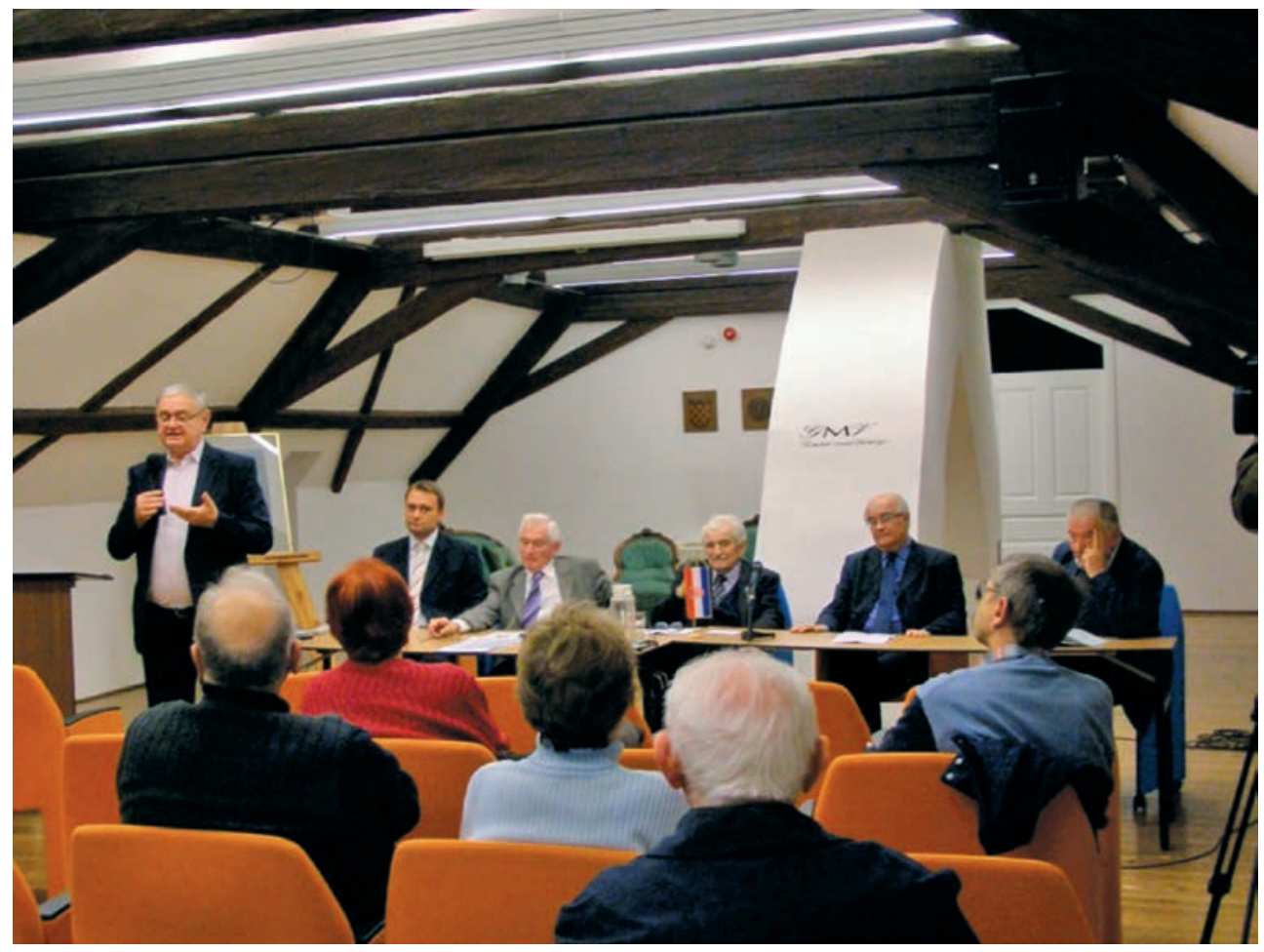

Slika 2. Hommage akad. Miroslavu Šicelu (4. 11. 2016.)

Veze akad. Miroslava Šicela s rodnim Varaždinon, pa onda i s Akademijinim Zavodom imaju svoju mnogo dužu povijest. ${ }^{9}$ Prema bilješkama dr. sc. Franje Ruža ${ }^{10}$ prof. Šicel bio je vrlo aktivan u motiviranju autora za istraživanja u velikom projektu 800 godina prvog spomena grada Varaždina 1181.-1981. Uz to Šicel objavljuje u časopisu Radovi 10-11 iz 1998. tekst „Književnopovijesni rad Ivana Kukuljevića Sakcinskog“. Nakon što je izabran za voditelja tiskano je nekoliko su njegovih priloga. ${ }^{11}$ Povodom navršenih 70 godina života 1997. realiziran je kolokvij posvećen

9 O vezama Šicela i Varaždina vidjeti više u tekstu: Eduard Vargović, Akademik Miroslav Šicel i Varaždin; KOLO, časopis Matice hrvatske za književnost, umjetnost i kulturu, Godište XIX, br. 5-6, Zagreb 2011. str. 120-134.

10 Prof. emmeritus dr. sc. Franjo Ruža, prvi je upravitelj varaždinskog Akademijinog Zavoda i predsjednik Odbora za obilježavanje 800 godina prvog spomena Varaždina 1181.-1981. Njegova bilješka o prof. Šicelu pohranjena je u dokumentaciji Zavoda.

11 Riječ je o slijedećim tekstovima: 1. „Šenoina „Kanarinčeva ljubovca“ u interpretaciji Jože Skoka“, Radovi 18, 2007., 2. "Predgovor", Grabar Ivan / Peričić Denis, Zavičajnost Miroslava Krleže, Zavod HAZU Varaždin, 2007. 
tek izabranom akademiku Miroslavu Šicelu. Kolokvij je održan 25. IV. a pripremali su ga: Ogranak MH Varaždin, Kajkavsko spravišće, Filozofski fakultet (katedra za noviju hrvatsku književnost), Društvo hrvatskih književnika i Zavod HAZU u Varaždinu. ${ }^{12}$ Međutim, dvije godine prije, 1995. Održan je u Varaždinu skup o Ivanu Belostencu..$^{13}$ Svi sudionici su se nakon skupa preselili u Lepoglavu gdje je u pavlinskoj crkvi Blažene Djevice Marije Belostencu u čast otkrivena spomen ploča. Cijeloj svečanosti prisustvovali su akad. Andre Mohorovičić, tada aktualni voditelj Zavoda i Miroslav Šicel budući voditelj. Tada je nastala jedina, nama poznata, zajednička fotografija.

Iz rečenog je nedvojbeno pokazana veza akad. Miroslava Šicela i Varaždina, pa time i Akademijinog Zavoda u Varaždinu. No, mnogo je važnija činjenica koja nam govori o osobnoj povezanost Varaždinaca, a to znači i nas u Zavodu sa svojim voditeljem i znamenitim sugrađaninom.

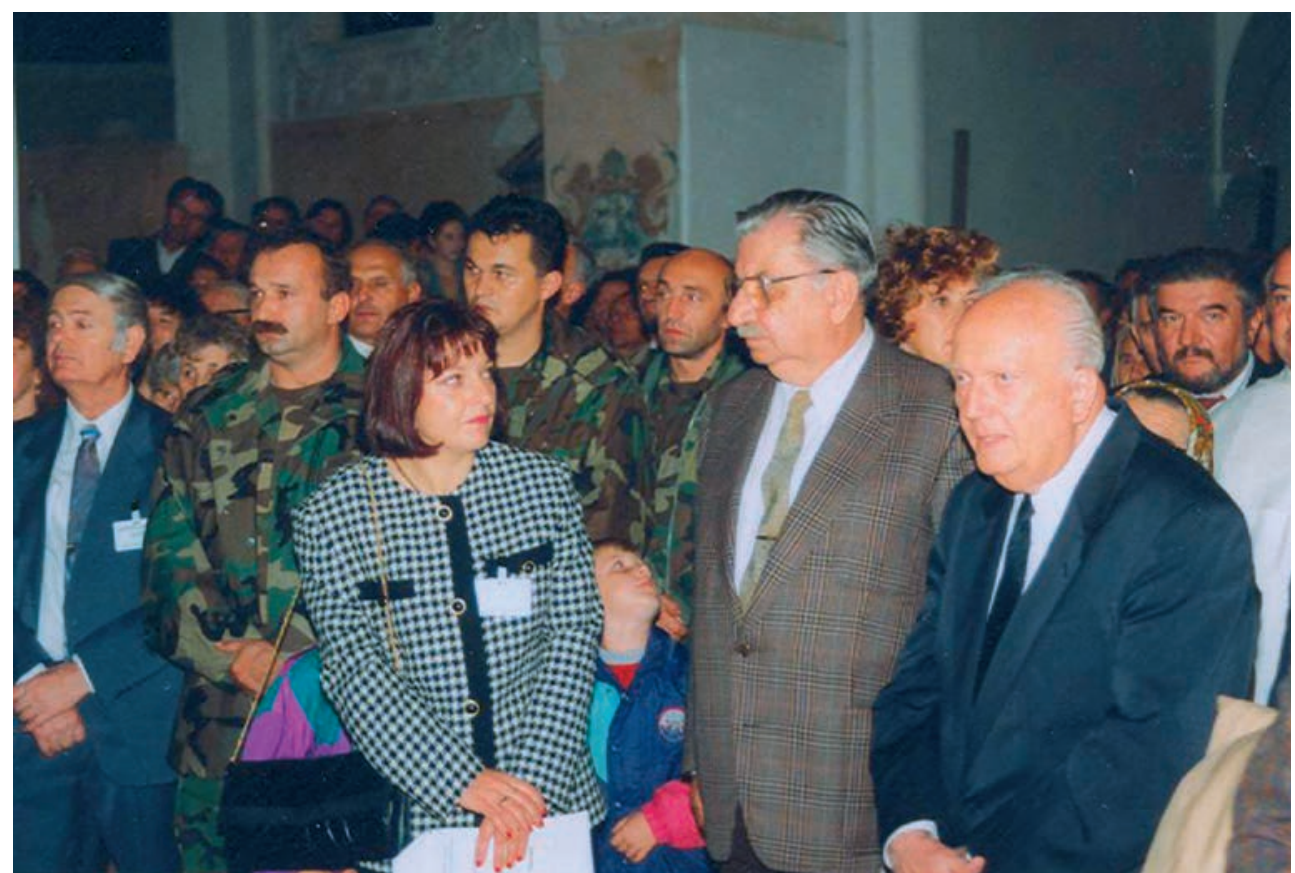

Slika 3. Zajednička fotografija u Lepoglavi prilikom otkrivanju spomen ploče Ivanu Belostencu (1995.)

12 Varaždinske vijesti, 17/1997.

13 Varaždinske vijesti, 42/1995. 


\section{ZAVOD U VRIJEME AKADEMIKA MIROSLAVA ŠICELA 2003. - 2011.14}

Aktivnosti Akademijinog Zavoda u Varaždinu u vrijeme djelovanja voditelja akad. Miroslava Šicela podijelit ćemo na nekoliko područja:

- Znanstveni skupovi, kolokviji i susreti

- Nakladnička djelatnost

- Izložbe

- Koncert

- Predavanja

- Ostale aktivnosti

\section{Znanstveni skupovi, kolokviji i susreti}

Tabela (broj 1) pregledno pokazuje znanstvene skupove, kolokvije i susrete koje je Zavod organizirao od 2003. do 2011. godine. Brojem, sadržajnošću i kvalitetom Zavod je obilježio velike i značajne obljetnice, važne ne samo za Varaždin, već i za cijelu Hrvatsku. Pritom je važno za istaknuti kako su mnogi skupovi bili međunarodnog karaktera, što je dodatno potvrdili njihovu kvalitetu.

U tabelu smo, pod brojem 6, uvrstili, predstavljanje časopis Radovi/18 iz 2007. Razlog je po našem mišljenju opravdam, jer su tom prilikom imali izlaganja svi autori koji su pisali o životu i radu prof. dr. sc. Jože Skoka, uz njegovu zahvala na kraju svečanog predstavljanja. ${ }^{15}$

14 Osnovu ovog pregleda, kao uostalom cijelog teksta čini odličan, i nezaobilazan tekst prof. dr. sc. Slobodana Kaštele, člana suradnika HAZU i zamjenika voditelja, koji je pripremljen u povodu 30. godina Akademijinog Zavoda u Varaždinu. Vidi cijelu studiju: S. Kaštela: „Trideset godina rada Zavoda za znanstveni rad Hrvatske akademije znanosti i umjetnosti u Varaždinu (1983. - 2012.), Radovi 24/2013., str. 11-68. Kao tajnik Hrvatske akademije S. Kaštela je razvio naročiti senzibilitet za rad Akademijinih Zavoda u Hrvatskoj i mnogo pomogao u njihovom radu uvažavajući vrijednosti sredina u kojima Zavodi djeluju. To vrijedi i za rad varaždinskog Zavoda. Tandem: Mohorovičić/Kaštela i Šicel/Kaštela svojim radom to i potvrđuje.

15 Svečanost predstavljanja bila je 12. prosinca 2007. Osim časopisa Radovi broj 18., bila je predstavljena i knjiga Ivana Grabara i Denisa Peričića, Zavičajnost Miroslava Krleže, također u izdanje Zavoda. 
Tablica 1. Znanstveni skupovi, kolokviji i susreti

\begin{tabular}{|c|c|c|c|}
\hline $\begin{array}{l}\text { Redni } \\
\text { broj }\end{array}$ & Naziv znanstvenog skupa & $\begin{array}{l}\text { Godina } \\
\text { održavanja }\end{array}$ & Organizatori \\
\hline 1. & $\begin{array}{l}\text { Međunarodni znanstveni skup: } 300 \\
\text { godina uršulinki u Varaždinu 1703. - } \\
\text { 2003. }\end{array}$ & Varaždin, 2003. & $\begin{array}{l}\text { Zavod HAZU Varaždin i Uršulinski } \\
\text { samostan u Varaždinu }\end{array}$ \\
\hline 2. & $\begin{array}{l}\text { Znanstveni skup: Adolf Jurinec- život } \\
\text { i djelo }\end{array}$ & Varaždin, 2004. & Zavod HAZU Varaždin i Gimnazija Varaždin \\
\hline 3. & \begin{tabular}{|l|} 
Međunarodni znanstveni skup: \\
Prometna povezanost Hrvatske \\
s europskim državama u funkciji \\
društveno-ekonomskog i kulturnog \\
razvoja Sjeverozapadne Hrvatske
\end{tabular} & Varaždin, 2005. & $\begin{array}{l}\text { Organizatori simpozija: Hrvatska akademija } \\
\text { znanosti i umjetnosti - Znanstveno vijeće } \\
\text { za promet, Zavod za znanstveni rad u } \\
\text { Varaždin. Suorganizatori su Varaždinska } \\
\text { županija, Međimurska županija, Grad } \\
\text { Varaždin, Grad Čakovec, Fakultet } \\
\text { prometnih znanosti, Fakultet organizacije i } \\
\text { informatike Varaždin, dok je pokrovitelj bila } \\
\text { Hrvatska gospodarska komora. }\end{array}$ \\
\hline 4. & \begin{tabular}{|l|} 
Znanstveni susret u povodu \\
dvadesete obljetnice smrti akademika \\
Ladislava Šabana
\end{tabular} & Varaždin, 2005. & $\begin{array}{l}\text { Zavod HAZU Varaždin i Varaždinske } \\
\text { barokne večeri }\end{array}$ \\
\hline 5. & $\begin{array}{l}\text { Znanstveni kolokvij posvećen } 80 . \\
\text { obljetnici rođenja i 55. obljetnici } \\
\text { stvaralaštva akademika Miroslava } \\
\text { Šicela }\end{array}$ & Varaždin, 2006. & $\begin{array}{l}\text { Razred za književnost, Hrvatske akademije } \\
\text { Zavod u Varaždinu, MH ogranak Varaždin i } \\
\text { Grad Varaždin. }\end{array}$ \\
\hline 6. & $\begin{array}{l}\text { Mjesto i uloga gimnazije u sustavu } \\
\text { obrazovanja }\end{array}$ & Varaždin, 2006. & Zavod HAZU Varaždin, Gimnazija Varaždin. \\
\hline 7. & $\begin{array}{l}\text { Svečano predstavljanje Radova/18, } \\
\text { uz izlaganja autora, - obljetnica Jože } \\
\text { Skoka }\end{array}$ & Varaždin, 2007. & Zavod HAZU Varaždin \\
\hline 8. & $\begin{array}{l}\text { Znanstveni skup Franjo Košćec i } \\
\text { njegovo djelo }\end{array}$ & Varaždin, 2008. & $\begin{array}{l}\text { Zavod HAZU Varaždin, Gradski muzej } \\
\text { Varaždin, Entomološki odjel, Prva gimnazija } \\
\text { Varaždin i Hrvatsko entomološko društvo } \\
\text { Zagreb }\end{array}$ \\
\hline 9. & $\begin{array}{l}\text { Međunarodni znanstveni skup u } \\
\text { povodu 800. obljetnice slobodnog } \\
\text { kraljevskog grada Varaždina 1209. - } \\
\text { 2009.1 }\end{array}$ & Varaždin, 2009. & $\begin{array}{l}\text { Zavod HAZU Varaždin, Grad Varaždin i } \\
\text { Varaždinska županija }\end{array}$ \\
\hline 10. & $\begin{array}{l}\text { Međunarodni znanstveni skup } 40 \\
\text { godina Varaždinskih baroknih večeri }\end{array}$ & Varaždin, 2010. & $\begin{array}{l}\text { Zavod HAZU } \\
\text { Varaždin, Varaždinske barokne večeri }\end{array}$ \\
\hline 11. & \begin{tabular}{|l} 
Značaj oslobođenja Varaždina za \\
Domovinski rat - okrugli stol u \\
povodu 20. obljetnice (1991.- 2011.)
\end{tabular} & Varaždin, 2011. & $\begin{array}{l}\text { Zavod HAZU Varaždin, Grad Varaždin i } \\
\text { Gradski muzej Varaždin }\end{array}$ \\
\hline 12. & $\begin{array}{l}\text { Znanstveni skup Mirko Malez i njegovo } \\
\text { djelo- uz 20. godišnjicu smrti }\end{array}$ & Ivanec, 2011. & Zavod HAZU Varaždin i Grad Ivanec \\
\hline
\end{tabular}

16 U povodu ove velike obljetnice HP tiskala je 2009. prigodnu poštansku marku. Upravo je ta marka 2009. proglašena markom godine. 


\section{Nakladnička djelatnost}

Nakladničku djelatnost Zavoda za ovu priliku podijelili smo u dvije cjeline:

- Časopis Radovi

- Ostala izdanja

\section{Časopis Radovi}

Časopis Radovi tiska se od 1986., dakle trideset godina, pa je ova, 2016., zapravo jubilarna. U vrijeme akad. Šicela tiskano je sedam knjiga, od toga dva dvobroja 14-15 u 2004. i 16-17 u 2006. Ujedno su to posljednji dvobroji časopisa. Iz tabele se jasno može vidjeti da je Zavod tiskanjem svoje edicije $\mathrm{u}$ isto vrijeme obilježavao u pojedinim brojevima važne obljetnice. To je programska zadaća Uredništva od samoga početka. Svim brojevima u razdoblju od 2003. do 2011. glavni i odgovorni urednik bio je akad. Miroslav Šicel. Iznimku čini broj 16-17/2006. koji je posvećen upravo prof. Šicelu, a glavni i odgovorni urednik bio je njegov zamjenik prof. dr. sc. Slobodan Kaštela, u to vrijeme već izabrani član suradnik Hrvatske akademije. ${ }^{17} \mathrm{Uz}$ spomenute činjenice treba dodati još jednu jako važnu. Riječ je digitalizaciji časopisa i njegovoj pojavi na portalu znanstvenih časopisa HRČAK. ${ }^{18}$ Ovaj će iskorak biti značajan doprinos važnosti časopisa. Tokom narednih godina časopis je zastupljen i na drugim portalima znanstvenih časopisa. ${ }^{19}$

Tablica 2. Nakladnička djelatnost - časopis Radovi

\begin{tabular}{|l|l|c|c|l|c|}
\hline $\begin{array}{l}\text { Redni } \\
\text { broj }\end{array}$ & Naziv časopisa & Broj & Godina & Obljetnice & $\begin{array}{c}\text { Broj } \\
\text { stranica }\end{array}$ \\
\hline 1. & Radovi & $14 / 15$ & 2004. & & 271 str. \\
\hline 2. & Radovi & $16 / 17$ & 2006. & Posvećeni akad. Miroslavu Šicelu & 308 str. \\
\hline 3. & Radovi & 18 & 2007. & $\begin{array}{l}\text { Posvećeni } \\
\text { profesoru dr. sc. Joži Skoku }\end{array}$ & 329 str. \\
\hline 4. & Radovi & 19 & 2008. & Uz 180. obljetnicu Glazbene škole Varaždin & 322 str. \\
\hline 5. & Radovi & 20 & 2009. & & 198 str. \\
\hline 6. & Radovi & 21 & 2010. & Uz 40. obljetnicu Varaždinskih baroknih večeri & 284 str. \\
\hline 7. & Radovi & 22 & 2011. & $\begin{array}{l}\text { Posvećeni 150. obljetnici HAZU i životu i radu } \\
\text { akademika Mirka Maleza. }\end{array}$ & 290 str. \\
\hline & & & & & 2002. str. \\
\hline
\end{tabular}

17 Tajnik Akademije prof. dr. sc. Slobodan Kaštela izabran je za člana suradnika Hrvatske akademije 18. 5. 2006. Voditelj je Zavoda za znanstveni i umjetnički rad u Bjelovaru (od 2008.).

18 Portal HRČAK je izrađen i radi uz potporu Ministarstva znanosti, obrazovanja i športa, realiziran je u Srcu, a osnovna ideja potekla je iz Hrvatskog informacijskog i dokumentacijskog društva.

19 To su redom: Hrvatska bibliografija, Niz C, Hrvatska akademija znanosti i umjetnosti, Digitalna zbirka Central and Eastern European Online Librarry (CEEOL), Ulrichs Web Global Serials Directory (ULRICH), Directory of Open Access Journals (DOAJ), a od broja 26/2015. časopis se referira i u uglednoj publikaciji: European Reference Index for the Humanities and Social sciences (ERIH Plus). 


\section{Ostala izdanja Zavoda}

Zavod je osim časopisa Radovi tiskao i druga izdanja. To je ponajprije nakladnički niz Posebna izdanja, ali i Pojedinačna izdanja. Oba nakladnička niza zastupljena su i u ovoj tabeli.

Uistinu je važno reći da se Zavod svojim radom u znanstvenoistraživačkim i nakladničkim projektima pokazao kao snažno središte okupljanja brojnih istraživača ne samo s našeg prostora nego i iz cijele Hrvatske, ali i iz drugih zemalja.

Tablica 3. Nakladnička djelatnost - ostala izdanja

\begin{tabular}{|c|c|c|c|c|c|}
\hline \begin{tabular}{|l} 
Redni \\
broj
\end{tabular} & Ime autora & Djelo & Godina izdanja & Obljetnica & $\begin{array}{l}\text { Broj } \\
\text { stranica }\end{array}$ \\
\hline 1. & Ivan Grabar & $\begin{array}{l}\text { Dvadeset godina Zavoda } \\
\text { za znanstveni rad Hrvatske } \\
\text { akademije znanosti i umjetnosti } \\
\text { u Varaždinu 1983. - 2003. }\end{array}$ & Varaždin, 2003. & $\begin{array}{l}20 \text { godina Zavoda u } \\
\text { Varaždinu }\end{array}$ & 128 str. \\
\hline 2. & Zbornik radova & $\begin{array}{l}\text { Tristo godina uršulinki u } \\
\text { Varaždinu 1703. - } 2003 .\end{array}$ & Varaždin, 2003. & $\begin{array}{l}300 \text { godina } \\
\text { uršulinki u } \\
\text { Varaždinu }\end{array}$ & 426 str. \\
\hline 3. & Zbornik radova & Adolf Jurinec i njegovo djelo & $\begin{array}{l}\text { Varaždin, } \\
2004 .\end{array}$ & $\begin{array}{l}\text { Program uz } 370 . \\
\text { godina varaždinske } \\
\text { gimnazije (danas } \\
\text { Prve gimnazije) }\end{array}$ & $114 \mathrm{str}$ \\
\hline 4. & Zbornik radova & \begin{tabular}{|l|} 
Prometna povezanost \\
Hrvatske s europskim \\
državama u funkciji društveno- \\
ekonomskog i kulturnog razvoja \\
Sjeverozapadne Hrvatske
\end{tabular} & Varaždin, 2005. & & 365 str. \\
\hline 5. & Zbornik radova & $\begin{array}{l}\text { Znanstveni susret u povodu } \\
\text { dvadesete obljetnice smrti } \\
\text { akademika Ladislava Šabana }\end{array}$ & Varaždin, 2005. & $\begin{array}{l}20 \text { godina od smrti } \\
\text { akad. Ladislava } \\
\text { Šabana }\end{array}$ & 92 str. \\
\hline 6. & Zbornik radova & $\begin{array}{l}\text { Znanstveni kolokvij posvećen } \\
\text { 80. O obljetnici rođenja i } \\
\text { 55. obljetnici stvaralaštva } \\
\text { akademika Miroslava Šicela }\end{array}$ & Varaždin, 2006. & $\begin{array}{l}\text { Obljetnice akad. } \\
\text { Miroslava Šicela }\end{array}$ & 99 str. \\
\hline 7. & $\begin{array}{l}\text { Ivan Grabar/ } \\
\text { Denis Peričić }\end{array}$ & Zavičajnost Miroslava Krleže & $\begin{array}{l}\text { Varaždin, } \\
2007 .\end{array}$ & & 177 str. \\
\hline 8. & Zbornik radova & Franjo Košćec i njegovo djelo & Varaždin, 2008. & $\begin{array}{l}40 \text { godina od smrti } \\
\text { Franje Košćeca }\end{array}$ & 325 str. \\
\hline 9. & Katalog izložbe & Život uz Dravu nekad i danas & Varaždin, 2008. & \begin{tabular}{|l} 
Izložba uz \\
znanstveni skup o \\
Franji Košćecu
\end{tabular} & 106. str. \\
\hline 10. & Ivan Grabar & $\begin{array}{l}\text { Varaždin i sjeverozapadna } \\
\text { Hrvatska u radovima } \\
\text { akademika Andre Mohorovičića }\end{array}$ & Varaždin, 2008. & $\begin{array}{l}\text { Uz 95. obljetnicu } \\
\text { akad. Andre } \\
\text { Mohorovičića }\end{array}$ & 141 str. \\
\hline
\end{tabular}


Eduard Vargović: Akademik Miroslav Šicel - voditelj Zavoda za znanstveni rad Hrvatske akademije znanosti i umjetnosti u Varaždinu... Radovi Zavoda za znanstveni rad HAZU Varaždin, br. 28, 2017., str. 285 - 301

\begin{tabular}{|l|l|l|l|l|l|}
\hline $\begin{array}{l}\text { Redni } \\
\text { broj }\end{array}$ & Ime autora & Djelo & Godina izdanja & Obljetnica & $\begin{array}{l}\text { Broj } \\
\text { stranica }\end{array}$ \\
\hline 11. & Zbornik radova & $\begin{array}{l}\text { Znanstveni skup u povodu } \\
\text { 800. obljetnice slobodnog } \\
\text { kraljevskog grada Varaždina } \\
1209 .-2009 .\end{array}$ & Varaždin, 2009. & $\begin{array}{l}\text { Uz 800 obljetnicu } \\
\text { slobodnog } \\
\text { kraljevskog grada } \\
\text { Varaždina² }\end{array}$ & 927 str. \\
\hline 12. & $\begin{array}{l}\text { Stjepan Dvorski/ } \\
\text { Vladimir Kovšca }\end{array}$ & $\begin{array}{l}\text { Ekonomija za poduzetnike } \\
\text { (potpora Zaklade HAZU) }\end{array}$ & Varaždin, 2011. & $\begin{array}{l}\text { Uz 80 godina prof. } \\
\text { emeritus Franje } \\
\text { Ruže }\end{array}$ & 422 str. \\
\hline 13. & Vladimir Huzjan & $\begin{array}{l}\text { Djelovanje Zavoda za } \\
\text { znanstveni rad Hrvatske } \\
\text { akademije znanosti i umjetnosti } \\
\text { u Varaždinu 1983.-2011. }\end{array}$ & Varaždin 2011. & $\begin{array}{l}\text { Katalog izložbe } \\
\text { u povodu 150. } \\
\text { obljetnice Hrvatske } \\
\text { akademije 1861. - } \\
\text { 2011. }\end{array}$ & 64. str. \\
\hline & & & & 3386 str. \\
\hline
\end{tabular}

\section{Izložbe}

Organizacija izložbe, odnosno prezentacija vlastite djelatnosti jedan je od povremenih aktivnosti Zavoda. Treba reći da je Zavod često priređivao tzv. prigodne izložbe, primjerice uz predstavljanje svoje nakladničke djelatnosti ili neke obljetnice. Ipak, izložbe koje ovdje zapisujemo većeg su značaja, ali i sadržajno zahtjevnije.

Bilježimo ih kronološkim redom.

Prigodna izložba Dvadeset godina s akademikom Andre Mohorovičićem uz dvadeset godina Zavoda. Izložba postavljena u prostorijama Zavoda. (2003.).

Stalni izložbeni postav nakladničke djelatnosti Zavoda u prostorijama Zavoda. (2003.).

Godine 2005. Postavljena je u Zavodu prigodna izložba u povodu 190. obljetnice rođenja i 100. obljetnice smrti osnivača Hrvatske akademije Josipa Juraja Strossmayera.

Izložba u povodu 150. obljetnice utemeljenja HAZU - 1861. - 2011. Hrvatska akademija je pripremila veliku izložbu „Hrvatska akademija znanosti i umjetnosti kroz fotografije“. Sadržaji ove velike putujuće izložbe prilagođeni su prostorima u kojima su postavljani. U Varaždinu je to bio prostor u prizemlju palače Hercer Gradskog muzeja Varaždin.

20 Projekt i zbornik predstavljeni su javnosti 26.11.2009. u Vijećnici Grada Varaždina. Govorili su: Slobodan Mikac, zamjenik gradonačelnika, Franjo Ruža i Slobodan Kaštela.

21 Predstavljanje knjige održano je na dan smrti akad. Miroslava Šicela, 25.11. 2011. Tako je cijela svečanost zapravo započela prisjećanjima na poznatog Varaždinca i voditelja Akademijinog Zavoda u Varaždinu. 
Otvorenje je upriličeno 30. 11. 2007, a izložbe je bila o tvorena do 14. 12. Na otvorenju su govorili u ime Akademije, glavni tajnik akad. Slavko Cvetnić, te akad. Pavle Dešpalj, u ime Grada zamjenik gradonačelnika mr. sc. Ivan Mesek, a u ime Zavoda upravitelj mr. sc. Eduard Vargović.

Izložba o djelovanju Zavoda HAZU u Varaždinu, u povodu 150. obljetnice HAZU. Akademija je svojim programima cijelu 2011. obilježila 150. godina svojeg uspješnog djelovanja. Jedan od tih projekata je i bila velika izložba o djelovanju Zavod za znanstveni rad Hrvatske akademije u Varaždinu. Ispunivši svojim sadržajima cijeli prizemni prostor u palači Sermage Gradskog muzeja Varaždin Zavod je kroz brojne eksponate pokazao Varaždincima svoju djelatnost od 1983. kada je formiran pa sve do 2011., dakle 28 punih godina. Autor izložbe i odličnog kataloga bio je dr. sc. Vladimir, Huzjan, djelatnik u Zavodu, povjesničar i kustos. Uz raznovrsne sadržaje koji posjeduje Zavod autor izložbe uspio je angažirati i druge suradnike koji su ju svojim predmetima učinili naročito interesantnom. Tako su posjetitelji imali priliku vidjeti poseban dio s filatelijom, ali i dio s medaljama o djelovanju Akademije. Svečano otvaranje izložbe bilo je 9. prosinca 2011. Na otvorenju su govori: uvodno pozdravno slovo imao je upravitelj Zavoda u Varaždinu mr. sc. Eduard Vargović, koji je moderirao svečanost otvaranja izložbe. Govorili su: gradonačelnik Grada Varaždina Goran Habuš, zamjenica župana Varaždinske županija mr. sc. Blanka Glavica Ječmenica i autor izložba dr. sc. Vladimir Huzjan. Izložbu je otvorio u ime predsjednika Hrvatske akademije akad. Zvonka Kusića, potpredsjednik Akademije akad. Jakša Barbić. ${ }^{22}$ Ova je manifestacija bila bez dvojice prerano preminulih: voditelja akad. Miroslava Šicela i suradnika mr. sc. Ivana Grabara. ${ }^{23}$

Izložba o djelovanju Zavoda postavljena je 2012. u Bjelovaru u suradnji s tamošnjim Akademijinom Zavodom za znanstveni i umjetnički rad. ${ }^{24}$

Dio izložbe postavljen je i u Križevcima 2013. god. prilikom obilježavanja 100. godina rođenja akad. Andre Mohorovičića (1913. - 2003.). ${ }^{25}$

22 Prije otvorenja izložbe gradonačelnik Grada Varaždina Goran Habuš i župan Varaždinske županije Predrag Štromar, te njegova zamjenica mr. sc. Blanka Glavica Ječmenica primili su u Vijećnici Grada Varaždina delegaciju Hrvatske akademije na čelu s potpredsjednikom Hrvatske akademije akad. Jakšom Barbićem. Uz potpredsjednika Akademije delegaciji su bili: prof. dr. sc. Slobodan Kaštela, prof. emeritus Franjo Ruža, mr. sc. Eduard Vargović i dr. sc. Vladimir Huzjan.

23 Ivan Grabar iznenada je preminuo u listopadu, a M. Šicel u studenom 2011. god.

24 Izložba je otvorena 22. veljače 2012. Na otvorenju su govorili: Mladen Medar ravnatelj Muzeja, Vladimir Huzjan, autor izložbe, Slobodan Kaštela, voditelj Zavoda u Bjelovaru, Franjo Ruža, prvi upravitelj Zavoda u Varaždinu. Izložbu je prigodnim govorom otvorio akad. Jakša Barbić, potpredsjednik Hrvatske akademije.

25 Okrugli stol i prigodna izložba održani su u Križevcima 23. listopada 2013. 


\section{Koncert}

Hrvatska akademija je 2011. obilježila 150. godina svojeg postojanja i djelovanja. U čast obljetnice naše najviše znanstvene i umjetničke institucije Varaždinske barokne večeri u suradnji s Akademijinim Zavodom u Varaždinu posvećuje koncert: Hrvatska glazbena baština - Carlo Antonio Nagli, u obradi Ennija Stipčevića. Koncert je održan 27. rujna 2011. u Franjevačkoj crkvi u Varaždinu.

\section{Predavanja}

Cijelu 2005. godinu Hrvatska akademija je obilježavala 190. godina rođenja i 100. godina od smrti Josip Juraja Strossmayera. Varaždinski Zavod Hrvatske akademije priredio je predavanje akademika Petra Strčića Josip Juraj Strossmayer danas. Uvodno slovo imao je voditelj Zavoda akad. Miroslav Šicel, a pozdravnu Marijan Kraš, ravnatelj Gradske knjižnice i čitaonice Metel Ožegović. Predavanje, uz prigodnu izložbu, organizirano je 10. svibnja 2005.

Godina 2006. bila je godina Nikole Tesle. Zavod je organizirao predavanje akad. Vladimira Paara pod nazivom Nikola Tesla-znanstveni vizionar. Predavanje je, uz prigodnu izložbu, održano 27. studenoga 2006. u Gradskoj knjižnici i čitaonici Metel Ožegović.

\section{Nagrade}

U vrijeme djelovanja akad. M. Šicel dodijeljene su nagrade koje su svaka na svoj način bile vezane za rad i uspjehe Varaždinskog Zavoda.

Godine 2005. akad. Miroslav Šicel primio je od Grada Varaždina nagradu za životno djelo, koja mu je uručena na svečanosti u povodu Dana Grada Varaždina i blagdana Sv. Nikolu. Profesor Šicel se biranim riječima zahvalio u ime svih nagrađenih i u svoje ime. ${ }^{26}$

U godini kad je Zavod obilježio 25 godina, postojanja, 2008. dodijeljena mu je Plaketa Grada Varaždin, za uspjehe u istraživačkom radu, organizaciji znanstvenih skupova i u nakladničkoj djelatnosti. ${ }^{27}$

U povodu Dana Grada Varaždina 2010. upravitelj Zavoda Eduard Vargović dobio je Plaketu Grada Varaždina, za istraživački, nastavnički rad iza očuvanje knjižnog blaga Varaždina.

Kao i uvijek u tim prilikama nagrade su priznanja ali i obaveze koje valja savjesno realizirati.

\footnotetext{
26 Svečanost je održana 6. prosinca 2005. u Hrvatskom narodnom kazalištu u Varaždin.

27 Nagradu je, 2008. na svečanosti u povodu Dana Grada Varaždina i blagdana sv. Nikole, u ime Zavoda, primio zamjenik voditelja prof. dr.sc. Slobodan Kaštela, član suradnik HAZU.
} 


\section{Ostale aktivnosti}

Kad je riječ o ostalim aktivnostima, a njih je doista bilo mnogo, za ovu priliku spomenut ćemo one najvažnije, držeći se kronološkog reda događanja:

2003. godine obnovljene su prostorije Zavoda uz novčanu pomoć Grada Varaždina, a u povodu 20. obljetnice djelovanja Zavoda (1983.-2003.).

Projekt Ivan Werner nakon dvije godine rada završen je u 2003. god. i na taj način obrađena je njegova cjelokupna ostavština. Sve je snimljeno na CD i pohranjeno u Zavodu, Uršulinskom samostanu i Odsjeku za povijest hrvatske glazbe Hrvatske akademije. $^{28}$

Godine 2003. Inicijativom i pismom Zavoda, a uz potporu Grada Varaždina, Razredu za književnost predloženo je obilježavanje 80. obljetnice smrti Vatroslav Jagića. To je i ostvareno 11. studenoga predavanjem akademika Radoslava Katičića.

Inicijativom Visoke učiteljske škole u Čakovcu i u suradnji sa Zavodom $\mathrm{u}$ Varaždinu postavljena je 14.11. 2003. ispred Visoke učiteljska škole u Čakovcu bista akademika Vinka Žganca. Bistu je otkrio i prigodno govorio predsjednik Hrvatske akademije akad. Ivo Padovan.

Godine 2004. obilježila se 100. godišnjica rođenja akademika Ive Tomašeca. Zavod se uključio u tu proslavu u njegovom rodnom Novom Marofu, gdje su predsjednik Hrvatska akademije akad. Milan Moguš i dekanica Veterinarskog fakulteta dr. sc. Ljiljana Pinter otkrili poprsje akad. Tomašecu. Bilo je to 17. listopada 2004.

Početkom 2005. god. potpisan je novi (drugi) desetgodišnji Ugovor o djelovanju našeg Zavoda. Prvi je potpisan u prosincu 1994. Također je potpisan i Sporazum o međusobnim odnosima Županije i Grada. Na svečanosti potpisivanja bili su potpisnici: predsjednik Hrvatske akademije akad. Milan Moguš, župan Varaždinske županija dr. sc. Zvonimir Sabati i gradonačelnik Grada Varaždina dr. sc. Ivan Čehok. ${ }^{29}$ Činu potpisivanja prisustvovali su voditelj akad. Miroslav Šicel, njegov zamjenik prof. dr. sc. Slobodan Kaštela, član suradnik HAZU, i svi dosadašnji upravitelji: prof. emeritus Franjo Ruža, mr. sc. Ivan Grabar i aktualni mr. sc. Eduard Vargović. Podršku koju je dobio Zavod za svoj rad primljena je u Akademiji s naročitom pažnjom. Tako je uzorna suradnja nastavljena na obostrano zadovoljstvo.

2008. Odobrenjem Hrvatske akademije primljen je u radni odnos prof. Ivan Obadić $\mathrm{u}$ svojstvu asistenta. ${ }^{30}$ Bila je to velika pomoć $\mathrm{u}$ radu Zavoda posebno ako se ima $\mathrm{u}$ vidu veliki projekt 800. godina slobodnog kraljevskog grada Varaždina u 2009. godini.

\footnotetext{
28 Voditelj projekta bio je dr. sc. Ennio Stipčević. Studiju o Ivanu Werneru autor je objavio u Zborniku radova 300 godina uršulinki u Varaždinu 1703. - 2003., Varaždin 2003.

29 Ugovor je potpisan 17. siječnja 2005. u Salonu Gradske vijećnice Varaždin.

30 Ivan Obadić primljen je u radni odnos 3. studenog 2008.
} 
Godine 2010. umjesto kolege Ivana Obadića, koji odlazi na doktorski studij primljen je dr. sc. Vladimir Huzjan, današnji upravitelj Zavoda. ${ }^{31}$

Godine 2011. započela je digitalizacija svih izdanja Zavoda, uključujući i Varaždinski zbornik iz 1983., a završena je 2013. kada Zavod obilježava trideset godina uspješnog djelovanja.

Posebnu pažnju u svojem radu i organizaciji svakodnevnih aktivnosti Zavod je posvetio knjižnici, kao i dokumentaciji i njezinom sređivanju u skladu s pozitivnim zakonima čuvanja arhivske građe, a u suradnji s Hrvatskom akademijom i Državnim arhivom u Varaždinu.

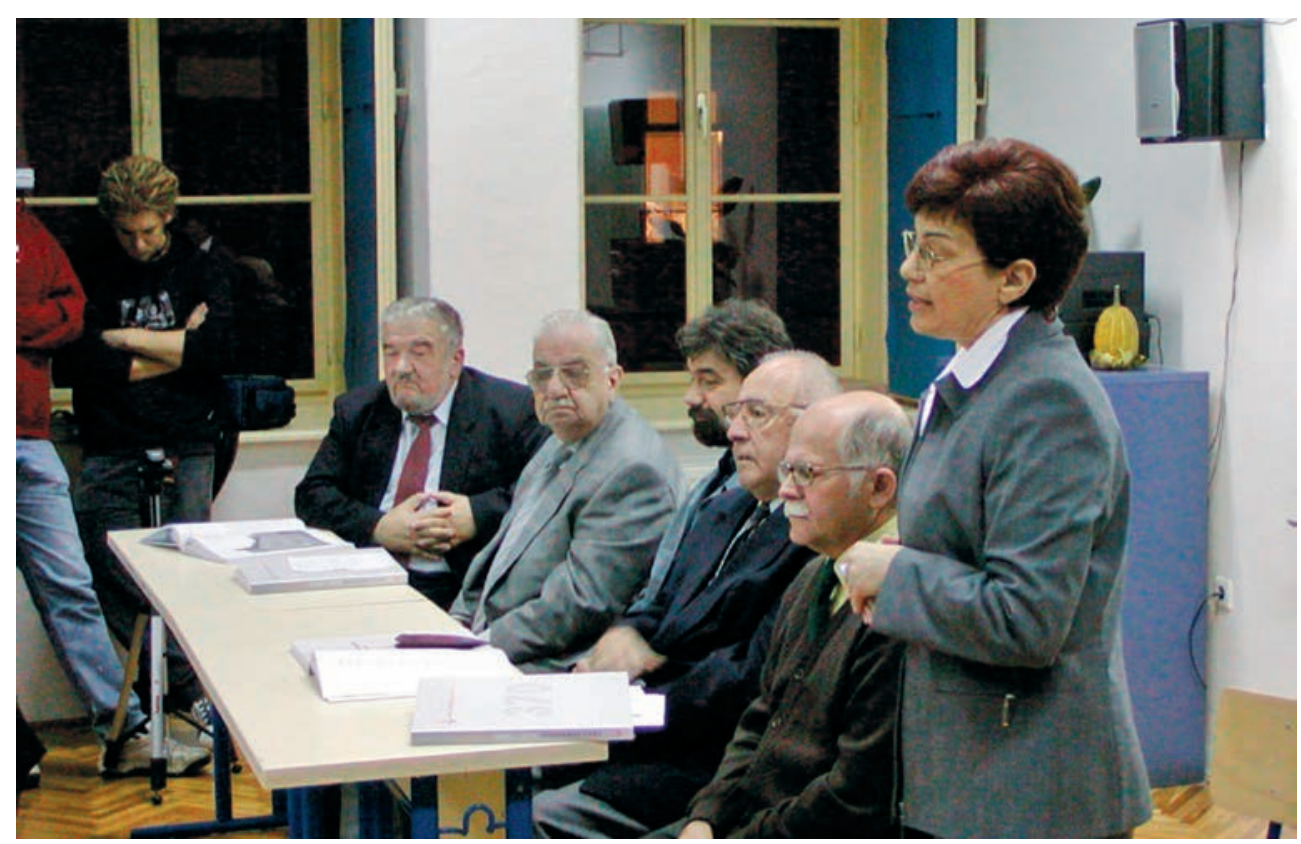

Slika 4. Na predstavljanju Monografije u povodu 370 godina gimnazije Varaždin 24. listopada 2006.

\section{Razmišljanja na kraju}

Odlazak velikih i dragih osoba stvara prazninu. S godinama ona je veća. Odlaskom prof. Šicela ostali smo bez neizmjerno drage osobe. Vedre, duhovite i druželjubive. Ali, odgovorne i savjesne, kreativne i dosljedne.

31 Vladimir Huzjan primljen je u radni odnos 7. lipnja 2010. godine. 
U osam i pol godina, koliko smo zajedno s našim voditeljem surađivali i realizirali brojne programe, uvijek smo mogli biti sigurni da ćemo kod prof. Šicela i prof. Kaštele imati punu podršku.

Svakako je to jedan od bitnih razloga velike i uspješne aktivnosti s vrlo dobrim rezultatima. Kad se sve pobroji, u vrijeme voditelja akad. Šicela, u Zavodu je tiskano trinaest knjiga i kataloga, sedam brojeva časopisa Radovi, održano 12 skupova, priređeno je sedam izložbi, dva predavanja i jedan koncert. Uz to i sve druge aktivnosti koje su važne za djelovanje Zavoda, odnosno Hrvatsku akademiju.

U vrijeme kad je bio voditelj Zavoda akad. Šicel radio je na svojim kapitalnim knjigama. ${ }^{32}$ To govori o njegovoj velikoj energije i začuđujućoj kreativnosti, u kojoj nikada nije nedostajalo ideja, ali i velike spremnosti da nas suradnike pažljivo sluša djelujući pritom strpljivo i s puno pouzdanja na realizaciji programa Zavoda.

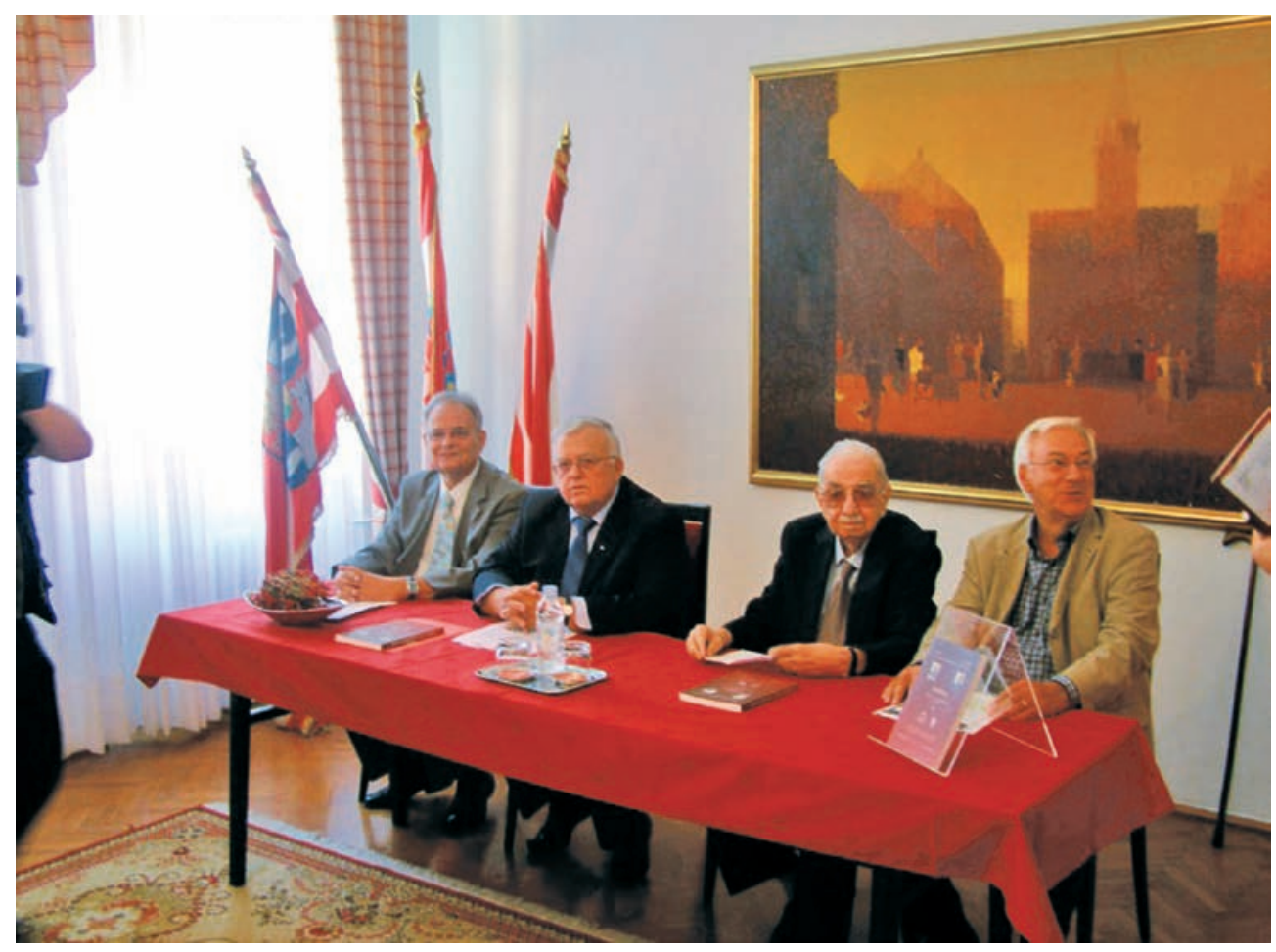

Slika 5. Na predstavljanju Radova 22/2011. u Vijećnici Grada Varaždina (rujan 2011.)

32 Riječ je o Povijesti hrvatske književnosti 1 (2004.), 2 (2005.), 3 (2005.) i 4 (2007.) sve u izdanju Naklade Ljevak d.o.o. u Biblioteci Posebna izdanja. 


\section{LITERATURA}

1. Ljetopisi Hrvatske akademije.

2. Ivan GRABAR, Dvadeset godina Zavoda za znanstveni rad Hrvatska akademije znanosti i umjetnosti u Varaždinu 1983.-2003. , Zavod HAZU Varaždin, Varaždin 2003.

3. Slobodan KAŠTELA, Trideset godina rada Zavoda za znanstveni rad Hrvatske akademije znanosti i umjetnosti u Varaždinu (1983.-2012.), Radovi 24/2013. str. 11-63.

4. Slobodan KAŠTELA, Trideset godina nakladničke djelatnosti Zavoda za znanstveni rad Hrvatske akademije znanosti i umjetnosti u Varaždinu, Bibliografija nakladničke djelatnosti Zavoda za znanstveni rad Hrvatske akademije znanosti i umjetnosti u Varaždinu (1983. - 2012.), Varaždin, Zavod HAZU Varaždin, Zagreb -Varaždin, 2013.

5. Tjednik Varaždinske vijesti, Varaždin.

6. Eduard VARGOVIĆ, Akademik Miroslav Šicel i Varaždin; KOLO, časopis Matice hrvatske za književnost, umjetnost i kulturu, Godište XIX, br. 5-6, Zagreb 2011. str. 120-134.

7. Dokumentacija Zavoda.

\section{SAŽETAK}

\section{AKADEMIK MIROSLAV ŠICEL - VODITELJ ZAVODA ZA ZNANSTVENI RAD HRVATSKE AKADEMIJE ZNANOSTI I UMJETNOSTI U VARAŽDINU 2003. - 2011.}

Akademik Miroslav Šicel izabran je za voditelja Zavoda za znanstveni rad Hrvatske akademije znanosti i umjetnosti u Varaždinu odlukom Predsjedništva Hrvatske akademije u ožujku 2003. godine.

Naslijedio je utemeljitelja i prvog voditelja Zavoda akad. Andre Mohorovičića, koji je svoju dužnost obavljao od 1983. sve do svoje smrti 2002. godine.

U nešto više od osam godina njegova vođenja, (do jeseni 2011.), u Zavodu je tiskano trinaest knjiga i kataloga, sedam brojeva časopisa Radovi, održano 12 skupova, priređeno je sedam izložbi, dva predavanja i jedan koncert. Naravno, uz to i sve druge aktivnosti koje su važne za djelovanje Zavoda, odnosno Hrvatske akademije.

Ako bi se htjelo najbolje opisati razloge snažnog i trajnog životnog djelovanja akad. Šicela kao voditelja Zavoda onda su to upravo njegove riječi iz Predgovora velikog Zbornika radova u povodu 800. godina slobodnog kraljevskog grada Varaždina 1209. - 2009. On piše: 
“Jer, znano je i potvrđeno: da bi znali kuda idemo, moramo znati odakle smo došli. Jedino samosvijest o vlastitoj tradiciji i njezinim vrijednostima omogućuje nam da cijenimo tu i takvu povijest, da volimo svoj grad i da ga unapređujemo. Samo ako sami cijenimo i poštujemo sve što smo naslijedili i stekli tek tada možemo očekivati da nas drugi cijene i poštuju."

Ključne riječi: hommage; akademik Miroslav Šicel; Zavod HAZU Varaždin.

\section{SUMMARY}

\section{ACADEMICIAN MIROSLAV ŠICEL - THE DIRECTOR OF THE INSTITUTE FOR SCIENTIFIC RESEARCH WORK OF THE CROATIAN ACADEMY OF SCIENCES AND ARTS IN VARAŽDIN 2003 - 2011}

Academician Miroslav Šicel was elected as a director of the Institute for Scientific Research Work of the Croatian Academy of Sciences and Arts in Varaždin by a decision of the Presidency of the Croatian Academy in March 2003.

He succeeded the founder and the first director of the Institute, academician Andre Mohorovičić, who had performed this duty from 1983 until his death in 2002.

In more than eight years, during which he led the Institute (until the autumn of 2011), thirteen books and catalogues, seven issues of the Radovi annual were published, twelve gatherings were held, seven exhibitions, two lectures and one concert were organised as well.

If one would wish to describe the reasons of strong and permanent life contribution of academician Šicel as the director of the Institute as best as possible, then one should use his own words from the Preface of the great Collection of Papers to commemorate 800 years of the free and royal town of Varaždin 1209 - 2009. He wrote:

"As it is known and confirmed: in order to know where we are going, we need to know where we come from. Only the self-awareness of our own tradition and its values enables us to appreciate this and such history, to love our town and to strive to make it better. Only if we appreciate and respect everything we have inherited and accomplished, can we expect that others will appreciate and respect us as well. "

Key Words: homage; academician Miroslav Šicel; HAZU Institute Varaždin..$^{33}$

\footnotetext{
33 Sažetak prevela Sanja Županić, prof.
} 